\title{
Ponceau 4R: A Novel Staining Agent for Resolve Food Proteins on PAGE and Its Impact on Digestibility
}

\author{
Syed Muhammad Ghufran Saeed ${ }^{1}$, Syed Asad Sayeed ${ }^{1}$, Seema Ashraf ${ }^{1}$, Lubna Mobin ${ }^{1}$, Syeda Siara Imtiaz ${ }^{1}$, \\ Adnan Shakeel ${ }^{1}$, Tabinda Zarren ${ }^{2}$, Rashida Ali ${ }^{1,2,3}$ \& Zafar Saieed Saify $^{2}$ \\ ${ }^{1}$ Department of Food Science and Technology, University of Karachi, Karachi, Pakistan \\ ${ }^{2}$ HEJ Research Institute of Chemistry, University of Karachi, Karachi, Pakistan \\ ${ }^{3}$ English Biscuit Manufacturers (Pvt.) Limited, Plot 1-4, Sector 23, Industrial Area, Karachi, Pakistan \\ Correspondence: Syed Muhammad Ghufran Saeed, Department of Food Science and Technology, University of \\ Karachi, Karachi, Pakistan. Tel: 92-213-4824-909. E-mail: smghufransaeed@gmail.com
}

Received: September 6, 2012 Accepted: November 16, 2012 Online Published: November 30, 2012

doi:10.5539/enrr.v3n1p8

URL: http://dx.doi.org/10.5539/enrr.v3n1p8

\begin{abstract}
Ponceaue 4R interaction with protein, Nisin and BSA was concentration dependent and may be used for protein assay. As the dye binds with almost all the proteins and current methodology may be used for the estimation of proteins in various food systems. During the course of present work staining with ponceau 4R of resolved proteins on PAGE (poly acryl amide gel electrophorosis) was comparable with Coommassie Brilliant Blue R250. The Ponceaue 4R was highly sensitive, rapid and produced sharp red bands on the gel on $0.2 \%$ concentration. The effects of $\mathrm{pH}$, concentration of proteins and dye were also investigated in various conditions which would help food processors to use a calculated amount of dye. The impact of tryptic digestibility on Ponceaue $4 \mathrm{R}$ -Protein Complexes (PPC) has illustrated that dye may safely be used without any adverse effect on the digestion of PPC.
\end{abstract}

Keywords: Ponceau 4R, Nisin, BSA, color bound protein, tryptic digestion, PAGE

\section{Introduction}

It is an age old practice to enhance food quality and its aesthetical appeal by incorporation of edible colors in a variety of food systems like candy, marshmallow, soft drink, vermicelli etc. Synthetic colorants with wide chemical diversity represent a well recognized group of food additives, performing the prime function not just to compensate the loss of natural colors during processing but also improving the appearance of the products. However, many of these dyes lead to health hazards (Downham \& Collins, 2000) as indicated by the World Health Organization (WHO) and Food and Agriculture Organization (FAO). Synthetic food colors are represented by major five groups, such as azo dyes, triarylmethane, chinophthalon derivatives of quinine yellow, xanthenes and indigo colorants (Minioti, Sakellariou, \& Thomaidis, 2007). Azo compounds are the most widely used dyes which are characterized by the presence of chromophoric azo bonds $(-\mathrm{N}=\mathrm{N}-)$ and include more than 300 components of different colors (Pardo, Yusa, Leon, \& paster, 2009).

Synthetic dyes, complexed especially with biopolymers are present in foods or in living organisms. Human serum albumin, bovine serum albumin and other proteins are known for their ability to form stable linkages with azo based colors (Sereikaite, Bumeleine, \& Bumelis, 2005). Inclusion complexes of some azo dyes with $\beta$-cyclodextrins are reported to be formed as illustrated by X-ray diffraction and UV spectrophotometery (Pardo et al., 2009). Natural flavonoids and carotenoids are reported to bind with proteins both in vivo and in vitro (Wade, Tollenaere, Hall, \& Degnan, 2009).

Some of the azo dyes such as Carmoisine (Saeed, Abdullah, Sayeed, \& Ali, 2010), Allura red (Abdullah, Badaruddin, Sayeed, Ali, \& Riaz, 2008), Sunst yellow (Badaruddin, Abdullah, Sayeed, Ali, \& Riaz, 2007) have already been proved to interact and bind with various food proteins. The in vitro digestibility of protein-azo dye complexes has also been investigated and it was found that it rarely affects the digestion process by the gut proteases (Saeed et al., 2011). Earlier studies reported some natural colors such as lawsone to bind with a variety of food proteins (Ali \& Sayeed, 1990; Ali, Sayeed, \& Khan, 1995). It seems that covalent bonds formed during the color and protein interactions do not disturb the overall configuration of proteins and allow enzymes to easily 
attack as in the usual kinetics.

Poncaeu 4R is available as a red powder. It is chemically known as the (4-sulpho-1-naphthylazo)-1-hydroxy-2-naptha-lene-6, 8-disulphonic acid trisodium salt (CI 16255) and has a molecular weight of $604.47 \mathrm{amu}$ (Zhong, Xu, \& Chen, 2005).

Ponceau $4 \mathrm{R}$ is well reported to interact with the biological molecules and more particularly with proteins. Currently differential pulse polarography using for the estimation of ponceua $4 \mathrm{R}$ in a mixture of Carmoisine and Allura that found in sweets and soft drinks (Chanlon, Joly-Pottuz, Chatelut, Vittori, \& Cretier, 2005). Even a simple spectrophotometric method was developed by using the first derivative of the ratio spectra involving determination at zero-crossing wavelength. This technique was later named as zero-crossing wavelength method which successfully separated the mixtures of three dyes such as Tartrazine, Sunset yellow and Ponceau 4R (Berzas, Flores, Cabanillas, Llerena, \& Salcedo, 1998). Recently a binary mixture of Carmoisine and Ponceau $4 \mathrm{R}$ was separated by using a simple sensitive and inexpensive technique of H-points Standard Adaptation Method (HPSAM) where a pair of wavelength $(460,549 \mathrm{~nm})$ was involved (Hajimahmoodi, Oveisi, Sadeghi, Jannat, \& Nilfroush, 2008).

Ponceau $4 \mathrm{R}$ is a safe food dye and has no harmful effects on the reproductive or neuro behavior in human beings as shown by evaluating the non observed adverse effect level (NOAEL) which is approximately $205 \mathrm{mg} / \mathrm{kg}$ body weight/day (Tanaka, 2006). The Ponceau 4R consumption in the daily diet is much lower than the suggested safe value (SSV).

Ponceau 4R shows its interaction with protein nisin, BSA and various nuts proteins including walnut, pistachio, peanut etc. The present study has illustrated that the staining ability of Ponceau 4R to stain different resolved food proteins on PAGE and also demonstrating the Ponceau 4R-protein complex (PPC) is concentration dependent. Moreover, the variation in $\mathrm{pH}$ is highly effective for configuration and structural stabilities of dye-protein complexes. It may be concluded that spectral analysis may be used to determine either dye or total protein in a mixture under specific condition.

\section{Materials and Methods}

\subsection{Materials}

$\mathrm{N}, \mathrm{N}$--methylenediacrylamide, acrylamide, Coomassie Brilliant Blue R 250 purchased from BDH, England, Tris (Trizma base) was obtained from Sigma-Aldrich Life Science USA. Ammonium peroxodisulfate (APS) from Omicron Sciences limited- London UK. Sodium dodecyl sulfate (SDS), glycine, bromophenol blue were supplied from Merck, 64271 Darmstadt, Germany. TEMED was purchased from Scharlu, Spain. BSA (bovine serum albumin) form BDH, England while Nisaplin (Nisin) was purchased from Suzhou Hengliang, China. The source of trypsin was fungal type XIII (from Aspergillus saitoi), Merck, Germany. Ponceau 4R was obtained from National Foods (Pvt) Ltd. All other chemicals were analytical grade. All aqueous solutions were prepared in double distill deionize (DDD) water.

\subsection{Methods}

\subsubsection{Proteins Solublzing Solution (PSS)}

The PSS ( $40 \mathrm{~mL}$ ) was prepared by mixing $9.6 \mathrm{~mL}$ of the $20 \%$ glycerol, $2.5 \%$ SDS (sodium dodecyl sulphate), $1.8 \mathrm{~mL}$ of mercaptoethanol and $8 \mathrm{~mL}$ of tris- $\mathrm{HCl}$ buffer of $\mathrm{pH} 6.8$, few crystals of bromophenol blue were also added as marker.

\subsubsection{Sample Preparation}

Twenty milligrams of BSA protein were dissolved in $1 \mathrm{~mL}$ of DDD water. The nut proteins solution of peanut, pistachio, walnut and almond were prepared by taking $5 \mathrm{~g}$ of fresh, crushed and defatted sample in $25 \mathrm{ml}$ of $0.5 \mathrm{M}$ phosphate buffer ( $\mathrm{pH}$ 7.6) to form thin slurry. The mixture was constantly stirred overnight in orbital shaker at $10^{\circ} \mathrm{C}$ and filter through fine cloth. The filtered protein solution was centrifuged at 10,000 rpm.

\subsubsection{Electrophoresis}

\subsubsection{Gel System}

A $10 \%$ polyacrylamide (acrylamide/bisacrylamide in the ratio of 30:0.8 [wt/wt]) was prepared according the method of Laemmli (1970). Briefly describing $20 \mu$ sample of protein were gently placed into the wells of gel (8 $\mathrm{cm}$ wide, $7.3 \mathrm{~cm}$ high, $0.75 \mathrm{~mm}$ thick). Protein samples were resolved by using the Bio-Rad Mini-Protean 3 cell system No. $67 \mathrm{~S} / 06917$, at a constant 120 Volt for $3 \mathrm{~h}$. 


\subsubsection{Staining Solutions}

Coomassie brilliant blue R-250 (0.2 g) was taken in $5 \mathrm{~mL}$ methanol with $7.5 \mathrm{~mL}$ acetic acid till total volume 100 $\mathrm{mL}$ with DDD Water. Similarly new staining agent Ponceau 4R was prepared with $8.5 \mathrm{~mL}$ acetic acid and $2 \mathrm{~mL}$ methanol.

\subsubsection{Destaining Solution}

The destaining solution for Commassie brilliant blue R-250 and Ponceau 4R was prepared by taken $30 \mathrm{ml}$ of methanol and $10 \mathrm{~mL}$ of glacial acetic acid till total volume $100 \mathrm{ml}$ with DDD water.

\subsubsection{Gel's Staining}

The polyacrylamide gel was stained in the Ponceau 4R staining agent overnight and washed several time with destaining solution of 20 minutes interval until clear appearance of red bands. Duplicate portion of overnight Coomassie blue stained gel was similarly destained as ponceau 4R which takes almost 24 hours.

\subsubsection{Protein Binding}

BSA and nisin proteins $(1 \mathrm{~mL})$ concentrations of $0,1.5,3,4.5,6,7.5,9,10.5,12,13.5$ and $15 \mathrm{mg} / \mathrm{mL}$ in separate test tubes were mixed with equal volume of Ponceau $4 \mathrm{R}$ solution $(2 \mathrm{mg} / \mathrm{mL})$ and incubated at $37^{\circ} \mathrm{C}$ for one hour. Protein solution was precipitated by adding $1 \mathrm{ml}$ TCA (40\%). Supernatant was decanted after centrifuge at 6000 $\mathrm{rpm}$ and total volume made $10 \mathrm{ml}$ with DDD water. Dye-Protein complex was measured by spectrophotometer at $505 \mathrm{~nm}$.

\subsubsection{Tryptic Digestion}

For the quantification of tryptic digestibility of Ponceau 4R bound proteins (BSA and nisin) were digested by trypsin enzyme $(1 \mathrm{mg} / 50 \mathrm{mg}$ of substrate) for different intervals of time (Pfleinderer \& Krauss, 1965). The reactions were stopped by adding $1 \mathrm{ml}$ of $10 \%$ TCA. The extent of proteolytic activity of the supernatant was measured spectrophotometrically at $280 \mathrm{~nm}$.

\subsubsection{Absorption Spectroscopy}

Different spectra in the region 400-750 nm wavelength were recorded by Spectrophotometer while the path length was $1 \mathrm{~cm}$. Experimental curve was constructed with variable $\mathrm{pH}$ as:

1). At constant BSA protein concentration

2). At constant Ponceau $4 \mathrm{R}$ concentration.

In both of the experimental designs, the stock solution of dye was $1 \mathrm{mg} / \mathrm{ml}$ while protein concentration was adjusted to $0.1 \mathrm{mg} / \mathrm{ml}$. For constant protein spectral assay, $1 \mathrm{ml}$ protein and known concentrations of ponceau $4 \mathrm{R}$ as 5 to $30 \mu \mathrm{l}$ were adjusted to volume $1 \mathrm{ml}$ by using phosphate buffer at different $\mathrm{pH}$. Same methodology was followed for constant dye assay by adjusting protein concentration as 5-25 $\mu$ l adjusting volume $1 \mathrm{ml}$ by using phosphate buffer at different $\mathrm{pH}$.

\subsubsection{Statistical Analysis}

Statistical analysis was performed by Minitab version 13.1. The regression analysis for digestibility showed that the linear relation to the time interval of the exposition to the enzyme. The ' $r$ ' values were in the range of 0.96-0.99. The ' $\mathrm{p}$ ' values calculated were $<0.005$.

\section{Results and Discussion}

\subsection{Protein Binding through PAGE}

The present study is illustrating through PAGE shows the strong binding potential with various food proteins. In order to explain the staining ability of Ponceau 4R, the related factors are compared in table 1 with the standard dye Coomassie brilliant blue R-250. Ponceau 4R is nontoxic and takes only $1 \frac{1 / 2}{2}$ hour in destaining while the Coomassie brilliant blue R-250 bands are clearly seen after $48 \mathrm{hrs}$. Although the protein bands in case of Ponceau $4 \mathrm{R}$ are lighter but they appear to be very sharp at $0.2 \%$ concentration than Coomassie brilliant blue R-250. The different protein bands, stained with the two dyes as shown in Figure 1, have demonstrated the equivalent ability of binding with the various proteins.

It has been shown that Ponceau 4R binding with proteins by electrostatic and hydrophobic interactions due to complex formations at the surfaces of protein molecules. It also has been estimated in minute quantity as reported earlier using resonance light spectroscopy (Zhong et al., 2005). The nature of linkages involve in dye-protein complexes other than electrostatics forces and hydrophobic bonding but also hydrogen bonding and vander wall forces as demonstrated by the multiple experiments conducted earlier (Tal, Silberstein, \& Nusser, 
1985).
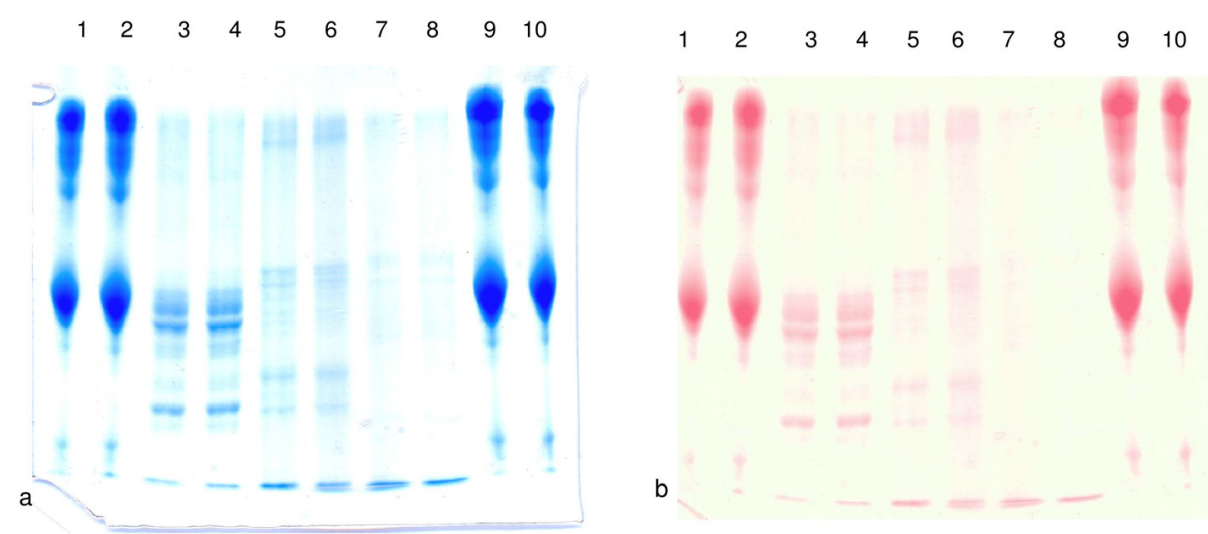

Figure 1. The samples of BSA (lane 1,2, 9, 10), peanut (lane 5, 6), almond (lane 7, 8) resolved and stained with (a) Coomassie brilliant blue R 250 and (b) Ponceau 4R

It seems that present method being, rapid, economical and safe, may be used as a staining agent for routine analysis in PAGE especially in future research where immediate results are often desired.

\subsection{Protein Binding through Absorption Spectroscopy}

The binding of protein with Ponceau 4-R dye can be measured by absorption spectrophotometry at $507 \mathrm{~nm}$. Protein-dye binding may be defined as the chemical interaction of the two molecules. The amount of ponceau 4-R is kept constant throughout the experiments the only change that occur is in the concentration of proteins. When protein is precipitated by TCA simultaneously the proteins with Ponceau 4-R interaction get minimized as demonstrated in Figure 2.

Protein binding in presence Ponceau 4R

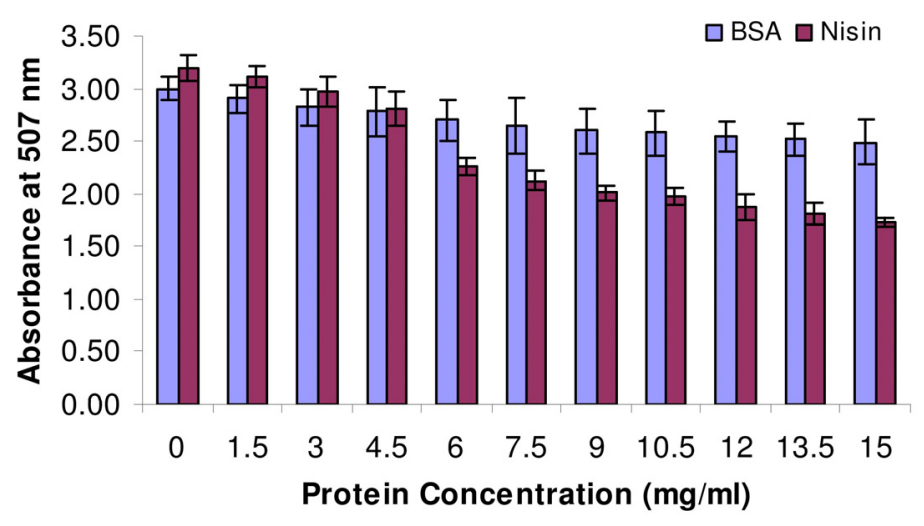

Figure 2. In vitro Protein binding of BSA-dye \& Nisin-dype complexes at various protein concentrations

\subsection{Protein Digestibility}

The protein digestibility was estimated through spectrophotometer. In case of BSA-Ponceau complex has low absorbance as compared to the BSA unbounded dye but in case of nisin-Ponceau complex modifies digestibility and a decrease is observed in absorbance at $280 \mathrm{~nm}$ in comparison to unbounded nisin (Figure 3). These results described the digestion quality of protein as well as the impact of enzyme and also exhibited the binding capacity of Ponceau 4R with food proteins. 


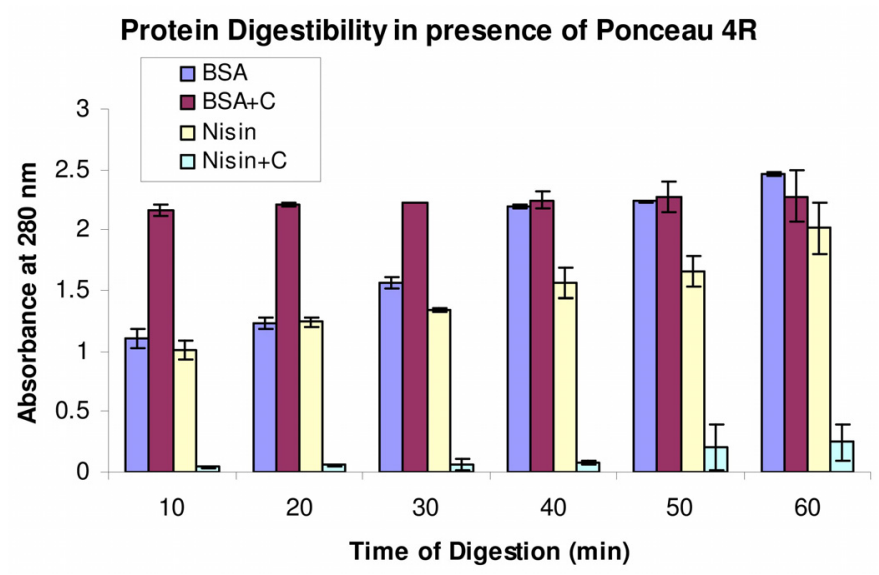

Figure 3. In vitro digestiblity of BSA \& Nisin proteins (control) and dype complexes

Serum albumin has affinity to bind with negatively charged hydrophobic molecules which may interact with the aromatic regions of the dyes (Peters, 1985). Higher degree of helical contents of BSA molecule that contain cylindrical open channel with suitable functional groups can easily occupy dye molecules (Brodersen, Honore, Pedersen, \& Klotz, 1988). Trypsin enzyme cleaved the basic amino acid residues such as lysine and arginine from the C-terminal of protein molecule so it partially digests both BSA and nisin proteins.

Serum albumin consists of three domains such as 1-80, 187-372 and 379-570 residues of amino acids (Brown, 1975). Amino acid sequence of BSA and Nisin molecules with their possible binding and digestion sites are given in Figure 4. BSA is a bigger molecule contains 607 amino acid residues in 156 amino acids (26\%) may act as interaction sides for dye binding while Nisin is small protein molecule with 57 amino acid residues in which 10 amino acids (17.5\%) may act for dye binding. Finally tertiary structure of both proteins and ionic environment decides the binding with dye and its mechanism of digestibility.

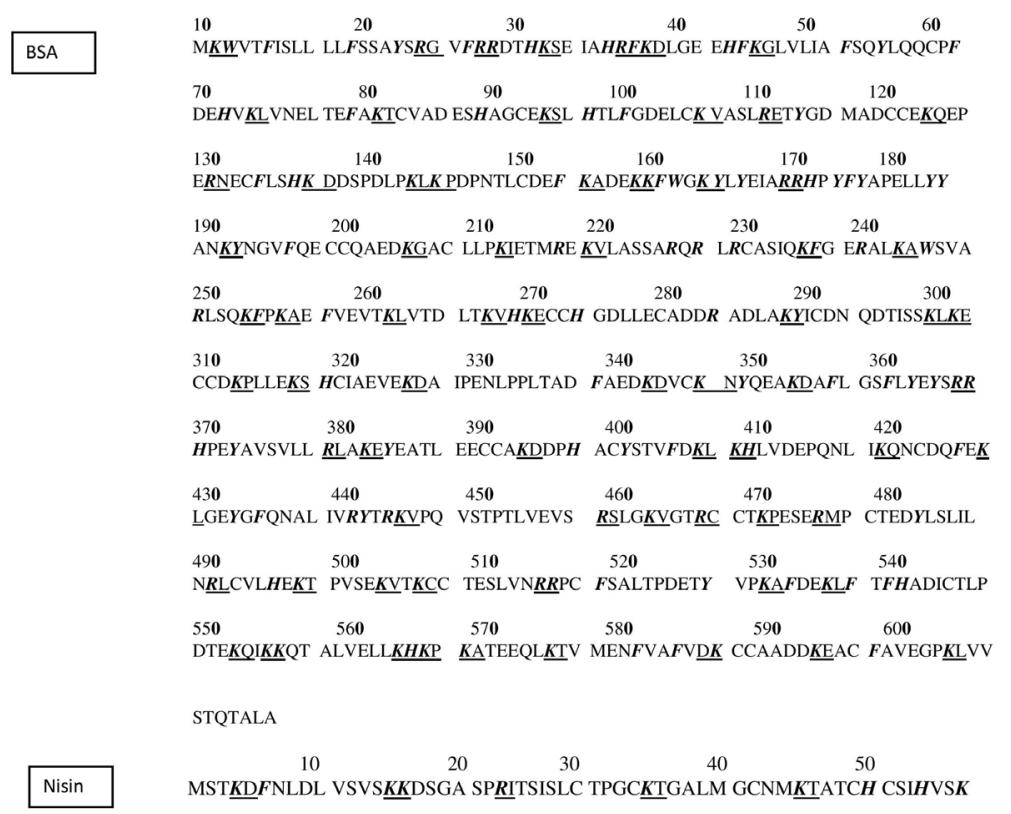

Figure 4. The amino acid sequence of BSA and Nisin is obtained from Swiss-Prot with accession number P02769 and P13068 respectively. The two amino around the cleavage sites found for trypsin digestions are underlined and possible dye binding amino acids are shown in bold 


\subsection{Structural Elucidation Absorption Spectroscopy}

According to the observation of Figure 5A, the concentration of BSA protein is constant while the concentration of dye Ponceau 4R changed at different $\mathrm{pH}$. Variation in $\mathrm{pH}$ causes the folding and unfolding of BSA molecule which also demonstrating through spectral observations. Figure 5B illustrates that concentration of protein increases and dye concentration remains constant than binding observed in the order $\mathrm{pH} 2>\mathrm{pH} 10>\mathrm{pH} 7>\mathrm{pH}$ $4>\mathrm{pH} 3$.
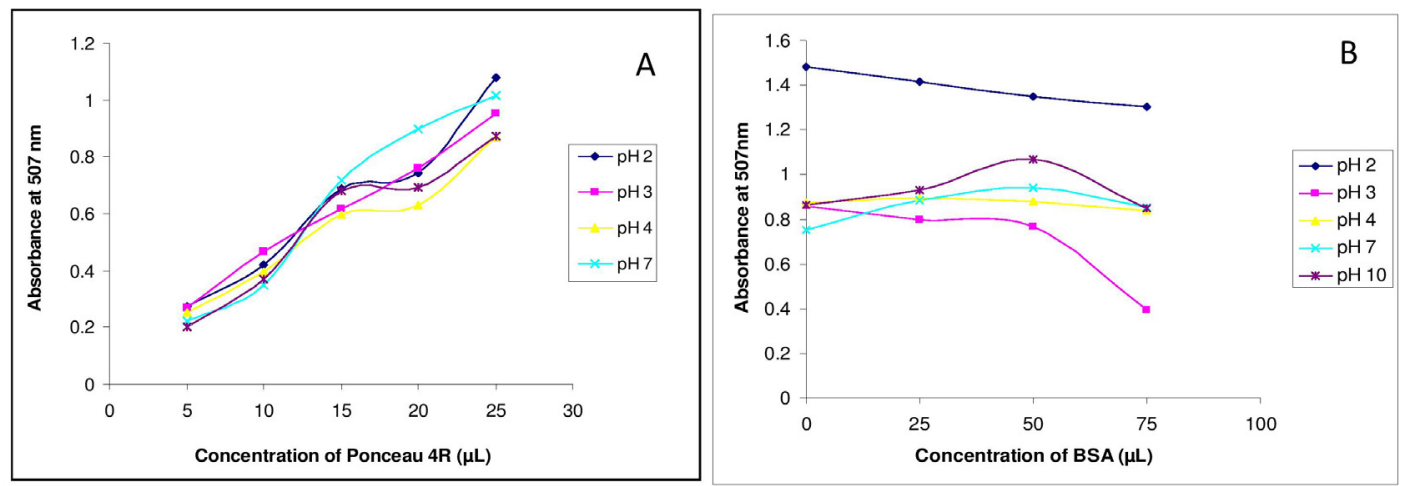

Figure 5. Absorption curve of the (A) BSA protein $(0.1 \mathrm{mg} / \mathrm{ml})$ with variable concentratain of Ponceau 4R $(1 \mathrm{mg} / \mathrm{ml})$ with variable concentration of BSA protein at different $\mathrm{PH}$

The $\mathrm{pH}$ variation causes the reversible conformational isomerization in Serum albumin (Foster, 1977). That's why the variation in absorbance was not only due to the $\mathrm{pH}$ but also vary with concentration of dye. The folding and unfolding of protein molecule provides the different number of negatively charged amino acids where electrostatitic binding can possible. BSA molecules behave reversible transition of $\mathrm{N}$ (normal) to $\mathrm{F}$ (fast) form at $\mathrm{pH} 4.3$ is due to the domain III unfolding in which helix unfolding shift from 55\% to $45 \%$ (Geisow, 1977; Khan, 1986). The unfolding of helical structure of $\mathrm{F}$ (fast) form is responsible for increase in viscosity and decrease in solubility (Foster, 1960). At pH below 4, albumin undergoes expansion with degradation of the intra-domain helices $(35 \%)$ called expanded (E) form achieved at $\mathrm{pH} 2.7$ which increase viscosity (Harrington, Johnson, \& Ottewill, 1956). At pH 9 albumin molecule shift in basic form (B) with $48 \%$ helix. Albumin molecule isomerizes in aged (A) form at $\mathrm{pH} 9$ with low ionic strength for 3 to 4 days at refrigeration temperature.

\section{Conclusion}

The rapid and simple staining procedure and clear visualization of the stained protein band with Ponceau 4R can be used as a novel staining agent as routine PAGE analysis. The binding of color depends on $\mathrm{pH}$ exhibited by spectrophotometeric investigation. Sharpness of ponceau 4R color not altered in acidic or basic environment. It can be clearly seen that the binding of both proteins BSA and Nisin varies differently due to the difference in their molecular structure. It has been proved for the first time that the digestibility of protein was not affected in presence of ponceau $4 \mathrm{R}$.

\section{Acknowledgements}

We are thankful to the Dean Faculty of Science, University of Karachi for the partial financial support.

\section{References}

Abdullah, S. U., Badaruddin, M., Sayeed, S. A., Ali, R., \& Riaz, M. N. (2008). Binding ability of Allura Red with food proteins and its impact on protein digestibility. Food Chemistry, 110, 605-610. http://dx.doi.org/10.1016/j.foodchem.2008.02.049

Ali, R., Sayeed, S. A., \& Khan, A. A. (1995). A sensitive novel staining agent for the resolved proteins on PAGE. Int J Peptide protein Res, 45, 97-99. http://dx.doi.org/10.1111/j.1399-3011.1995.tb01026.x

Ali, R., \& Sayeed, S. A. (1991). A plant dye from Lawsonia inermis for protein staining after polyacrylamide gel electrophorsis. Electrophorsis, 11, 343-344. http://dx.doi.org/10.1002/elps.1150110414

Badaruddin, M., Abdullah, S. U., Sayeed, S. A., Ali, R., \& Riaz, M. N. (2007). Sunset Yellow: A Food Color for 
Protein Staining with SDS-PAGE. Cereal Foods World, 52, 12-14.

Berzas, N. J. J., Flores, R., Cabanillas, C. G., Llerena, M. J. V., \& Salcedo, A. S. (1998) Resolution of ternary mixtures of Tartrazine, Sunset yellow and Ponceau 4R by derivative spectrophotometric ratio spectrum-zero crossing method in commercial foods. Talanta, 46, 933-942. http://dx.doi.org/10.1016/S0039-9140(97)00348-2

Brodersen, R., Honore, B., Pedersen, A.O., \& Klotz, I.M. (1998). Binding constants for ligand-carrier complexes. Trends Pharmacol Sci, 7, 252-257. http://dx.doi.org/10.1016/0165-6147(88)90155-1

Brown, J. R. (1975). Structure of Bovine serum albumin. Fed Proc, 34, 591-59.

Chanlon, S., Joly-Pottuz, L., Chatelut, M., Vittori, O., \& Cretier, J. L. (2005). Determination of Carmoisine, Allura red and Ponceau 4R in sweets and soft drinks by Differential Pulse Polarography. J Food Comp Anal, 18, 503-513. http://dx.doi.org/10.1016/j.jfca.2004.05.005

Downham, A., \& Collins, P. (2000). Colouring our foods in the last and next millenium. Int J Food Sci Tech, 35, 5-22. http://dx.doi.org/10.1046/j.1365-2621.2000.00373.x

Foster, J. F. (1960). In The Plasma Proteins (Putnam, F. W. ed.), London and New York: Academic Press. pp. 179-239.

Foster, J. F. (1977). Serum albumin. In: Rosenoer, V. M., Oratz, M., \& Rothschild, M. A. (eds.). Albumin structure, function and uses. Oxford: Pergamon. pp. 53-84.

Geisow, M. J., \& Beaven, G. H. (1977). Physical and binding properties of large fragments of human serum $\begin{array}{llll}\text { albumin. } & \text { Biochem } & \text { 477-484. }\end{array}$ http://www.ncbi.nlm.nih.gov/pmc/articles/PMC1164727/pdf/biochemj00511-0089.pdf

Hajimahmoodi, M., Oveisi, M., Sadeghi, N., Jannat, B., \& Nilfroush, E. (2008). Simultaneous Determination of Carmoisine and Ponceau 4R. Food Anal Methods, 1, 214-219. http://dx.doi.org/10.1007/s12161-008-9022-7

Harrington, W. F., Johnson, P., \& Ottewill, R. M. (1956). Bovine serum albumin and its behaviour in acid $\begin{array}{lllll}\text { solution. } & \text { Biochem } & & 62, & \end{array}$ http://www.ncbi.nlm.nih.gov/pmc/articles/PMC1215964/pdf/biochemj00858-0044.pdf

Khan, M. Y. (1986). Direct evidence for the involvement of domain III in the N-F transition of bovine serum $\begin{array}{llll}\text { albumin. Biochem 307-310. } & \text {. }\end{array}$ http://www.ncbi.nlm.nih.gov/pmc/articles/PMC1146822/pdf/biochemj00279-0296.pdf

Laemmli, U. K. (1970). Cleavage of structural proteins during the assembly of the head of bacteriophage T4. Nature, 227, 680-685. http://dx.doi.org/10.1038/227680a0

Minioti, K. S., Sakellariou, C. F., \& Thomaidis, N. S. (2007). Determination of 13 synthetic food colorants in water-soluble foods by reversed-phase high-performance liquid chromatography coupled with diode-array detector. Anal Chim Acta, 583, 103-110. http://dx.doi.org/10.1016/j.aca.2006.10.002.

Pardo, O., Yusa, V., Leon, N., \& Pastor, A. (2009). Development of a method for the analysis of seven banned azo-dyes in chilli and hot chilli food samples by pressurised liquid extraction and liquid chromatography with electrospray ionization-tandem mass spectrometry. Talenta, 78, 178-186. http://dx.doi.org/10.1016/j.talanta.2008.10.052

Peters, T. Jr. (1985). Serum albumin. Adv. Protein Chem 37, 161-245. http://dx.doi.org/10.1016/S0065-3233(08)60065-0

Pfleinderer, G., \& Krauss, A. (1965). Spectrophotometric assay for the detection of protease activity. Biochem Z, $85,342-344$.

Saeed, S. M. G., Abdullah, S. U., Sayeed, S. A., \& Ali, R. (2010). Food protein: food colour interactions and its application in rapid protein assay. Czech J. Food Sci, 28, 506-513. http://dx.doi.org/10.6000/1927-5951.2011.01.01.07

Saeed, S. M. G., Sayeed, S. A., Ashraf, S., Nassimunnisa, Batool, F., Ali, R., Naz, S., \& Siddiqi, R. (2011) Investigations of In vitro Digestibility of Proteins Bound to Food Colors. J. Pharm and Nut Sci, 1, 34-40. http://dx.doi.org/10.6000/1927-5951.2011.01.01.07

Sereikaite, J., Bumeliene, Z., \& Bumelis, V. A. (2005). Bovine Serum Albumin-Dye Binding. Acta Chromatographica, 
Tal, M., Silberstein, A., \& Nusser, E. (1985). Why does Coomassie Brilliant Blue R interact differently with different proteins? A partial answer. J. Biol Chem, 260, 9976-80. http://www.jbc.org/content/260/18/9976.full.pdf + html

Tanaka, T. (2006). Reproductive and neurobehavioural toxicity study of Ponceau 4R administered to mice in the diet. Food and Chemical Toxicology, 44, 1651-1658. http://dx.doi.org/10.1016/j.fct.2006.05.001

Wade, N. M., Tollenaere, A., Hall, M. R., \& Degnan, B. M. (2009). Evolution of a Novel Carotenoid-Binding Protein Responsible for Crustacean Shell Color. Mol. Biol. Evol, 26, 1851-1864. http://dx.doi.org/10.1093/molbev/msp092

Zhong, H., Xu, J. J., \& Chen, H. Y. (2005). A rapid and sensitive method for the determination of trace proteins based on the interaction between proteins and Ponceau 4R. Talanta, 67, 749-754. http://dx.doi.org/10.1016/j.talanta.2005.03.027 